\title{
Experience-Based Learning in Nursing Teacher Education: A Historical-Cultural Research Study
}

\author{
Marlene Fagundes Carvalho Gonçalves ${ }^{1, *}$, RonildoAlves dos Santos ${ }^{1}$, Marta AngélicaIossi Silva², Cinira Magali \\ Fortuna $^{2}$, LucianeSá de Andrade ${ }^{1}$ \\ ${ }^{1}$ Psychiatric Nursing and Human Sciences, University of São Paulo at Ribeirao Preto College of Nursing, Ribeirao Preto, Brazil \\ ${ }^{2}$ Maternal-Infant and Public Health, University of São Paulo at Ribeirao Preto College of Nursing, Ribeirao Preto, Brazil \\ *Corresponding author: mgoncalves@eerp.usp.br
}

Received March 17, 2014; Revised May 04, 2014; Accepted May 12, 2014

\begin{abstract}
The Ribeirão Preto College of Nursing at the University of São Paulo trains nurses and nursing teachers, providing undergraduate students with tasks within different health and education context throughout their degree course. This article analyses those students' experiences outside the university via the "Health Promotion in Basic Education" course, which adopts the following pedagogical cycle: Immersion in professional practice scenarios, provisional synthesis, searching for theoretical support, new synthesis and assessment. The investigated sample consisted of 21 portfolios written by students during this course. The data were studied in light of Bardin's theories of thematic analysis. These portfolios were personal and individual productions; however, they also referred to the groups and their experience. They showed the students' construction of knowledge and competencies. The importance of such student experience appeared during the course and supported the training of professionals who are better prepared and more critical, responsible and active in developing health promotion programs in schools.
\end{abstract}

\section{Keywords: Nursing Education, Human Resources Formation, Problem-Based Learning, Health Promotion}

Cite This Article: Marlene Fagundes Carvalho Gonçalves, RonildoAlves dos Santos, Marta AngélicaIossi Silva, Cinira Magali Fortuna, and LucianeSá de Andrade, "Experience-Based Learning in Nursing Teacher Education: A Historical-Cultural Research Study.” American Journal of Educational Research, vol. 2, no. 5 (2014): 316-324. doi: 10.12691/education-2-5-12.

\section{Introduction}

Recent curricular changes in undergraduate health courses in Brazil started at two specific moments. The first was the promulgation of the Federal Constitution of 1988 [1], which states that "health is a right of all” (art 196).The 1988 Federal Constitution institutes the Brazilian Unified Health System (SUS) and its guidelines: “decentralization, with central command at each level of government; whole healthcare, with priority placed on preventive actions; maintaining all health care services; community participation” (art. 198). Moreover, the Federal Constitution directs the SUS "to organize the formation of human resources in the health area” (art. 200). Since the enactment of the Constitution in 1988, the university has made a clear effort to construct and consolidate the SUS and define new professional roles that are more suitable to the social demands of quality in healthcare, emphasizing integration among teaching, service provision and social control [2].

The second moment of change occurred on December 20, 1996, with the promulgation of the National Education Guidelines and Framework Law [3]. This law states that education must be linked to the professional world and social practice while focusing on the development of the individual as a worker and a citizen (art. 1). Regarding higher education, the LDB highlights that "Students will be certified in different areas of knowledge, able to assume positions in professional sectors and to participate in the development of Brazilian society, contributing to its continuous development" (art. 43). Thus, curricular matters become central. With this purpose, in 1997, the Education Ministry asked the higher education institutions to present curriculum reformulation proposals to consolidate their guidelines.

In 2004, at the 12th meeting of the main national conference representing Brazilian society's interests in health, the National Conference of Health [4] stated that it was necessary "to change the model of health professional development, which is presently focused on disease. The reformulation of the professional health curriculum would consider theoretical and practical themes related to the promotion and monitoring of whole-person healthcare, social control and the multiprofessional and interdisciplinary character of health practices” (p. 127).

In the specific case of nursing, these concerns about curricular changes, the search for a new professional profile and the need for deeper participation in the SUS consolidation led to discussion forums in the National Seminars for Guidelines in Nursing Education (Senadens), coordinated by the Brazilian Nursing Association (ABEn) in 1994. These discussions led to the approval of the National Curricular Guidelines for Undergraduate Courses in Nursing [5] in November 2001. These guidelines define 
the principles, foundations, conditions and procedures for nursing students' training. Therefore, a new undergraduate profile was established: "Nurse - with generalist, humanistic, critical and reflexive education.” (3rd Art.).

With this profile in mind, didactic-pedagogical strategies were designed to update traditional pedagogical practices that have proven unable to produce the changes in practices and attitudes that are necessary in the new work organization modalities within health services. The new strategies also address the challenges posed by transdisciplinary models of education [6].

Such social movements changed the cultural reference for the practical development, training and teaching of nursing professionals in Brazil. "Cultural reference" in this context is a complex maze of symbols expressed in social interaction in which meanings are negotiated and conveyed [7].

This was the historical context in which the Ribeirão Preto College of Nursing at the University of São Paulo (EERP/USP) began in 2002, amid discussions about the adequacy of its pedagogical practices to meet the demands of the LDB and the directives of the SUS. The new curriculum was implemented in 2005 for the Bachelor of Nursing program (morning/afternoon) and in 2006 for the Bachelor and Degree in Nursing programs (afternoon/evening). The new pedagogical philosophy is based on dialogical competence in the integrated curriculum, in the application of training to real-life work and in problematizing methodology.

The dialogical approach to competence focuses mainly on meaningful learning based on theoretical-practical integration rather than content-based learning. Via reflection and theorization based on professional practice and real-life work situations, students and tutors build and develop their abilities/competencies. From this perspective, it is possible to work through the program contents by considering their meaningfulness and applicability to real situations [8].

Two decades ago, "teaching" used to refer to the transmission of knowledge based on relatively stable concepts. At present, teaching and learning intertwine, and concepts are temporary. This new approach emphasizes the need for students to process a vast amount of information and question its usefulness and to produce further knowledge. Therefore, we are facing important cultural shifts that require teachers and students to change their practices and values and lead them to new ways of teaching and learning.

Such cultural shifts do not happen smoothly by simply engaging and affecting individuals at the personal level. Such shifts encompass a scope that far beyond that of the individual willingness of and decisions by teachers, students and education professionals.

Thus, at present, EERP/USP trains nurses and nursing teachers and provides students with contact opportunities and activity development in different health and education contexts starting at the beginning of the program. Students are encouraged to acquire knowledge and create new approaches based on the reflections, inquiries and relationships they establish in their practical experience.

Examples of this proposal can be seen in the Health Promotion in Basic Education course taken by students in their second year of the Bachelor and Nursing Education degree programs. The educational practice in this discipline is developed through pedagogical cycles in which small groups of 12 to 14 undergraduate students participate along with a tutor who is a university professor. Each cycle comprises five distinct moments [9]:

1) Immersion in real-life work: Students, using previously acquired experience and knowledge, perform activities in professional practice scenarios.

2) Provisional synthesis: In groups, students read and discuss the reports that each student produced about the immersion experiences, identifying problems related to how actions were performed and generating a learning quest.

3) Search for information/knowledge: Working individually, the students survey various sources to support their answer to the learning quest.

4) New synthesis: Working in groups, the students reflect about their new information/knowledge, with the aim of understanding the identified problems and reconstructing the professional practice.

5) Evaluation: At the end of each activity, all participants undergo self-evaluation, group evaluation and tutor/facilitator evaluation [10].

Each of these moments of the cycle is reported in an individual reflection portfolio. This portfolio brings the students closer to the process they underwent. In writing their accounts, the students organize and reflect on their experiences.

This work process can be associated with the problematization methodology [11]. Despite its similarity to problem-based learning methodology [12], it differs because it adopts real-life situations as the themes to be approached. Students address the difficulties observed in real-life settings.

Therefore, this institution fosters nursing teacher development in the elementary school and health education contexts as essential elements of this training. For this purpose, it is necessary to recognize and accept nursing as social science and practice that can address the individual and collective needs of its subjects. The social and cultural contexts are of foremost importance because they shape health assistance within an epistemological approach that combines ethics and truly supportive relationships with human empowerment and emancipation and the evolution of societies [13].

Notably, Brazilian nursing traditionally operates inside school environments, especially with elementary students, their families and teachers, via health promotion social projects. Therefore, there is an effort to develop knowledge, skills and attitudes related to teaching in elementary school environments via health promotion projects based on cultural and social aspects of SUS education guidelines.

Various teaching projects within elementary education address extremely important themes in student health care, such as oral and mental health, adolescent health, accident and violence prevention and healthy diets. These themes follow the guidelines provided by The School Health Project (PSE / Ministry of Health) and the Adolescent Health Program (Prosad / Ministry of Health).

The need to address such themes is articulated in the National Guidelines for the Attention to Integral Health of adolescent and youth (DNAISAJ) and the multidisciplinary themes of the Brazilian National Curricular Parameters, namely health, growth and 
development follow-up, sex education, and sexuality and reproductive health, as well as integral assistance for those who abuse alcohol and other drugs.

In addition to the work with children, adolescents, youth and their families, there has been some work within teacher training projects regarding the management of various situations in the school environment. Such training aims to enable teachers to address the use or abuse of alcohol or other drugs and sexuality, especially as related to adolescent pregnancy and STD/AIDS prevention, as stated in the School Health Project of the Ministry of Health (PSE / MS).

The integration of nursing into elementary education considers the school as a learning space and a space with the potential to promote health. The school may offer a very productive atmosphere for educational practices and discussions of emerging health education topics and participation in and an understanding of a broader concept of health.

As professors in the Bachelor and Nursing Teacher degrees programs of EERP/USP who are responsible for the efforts mentioned above, the authors of this work are directly involved in this process of curricular change. The authors are responsible for both its implementation and its constant evaluation. One of the strategies for this evaluation is the analysis of students' experiences, as reported in the reflection portfolios. Because these portfolios are personal accounts, they refer to the group and bring to light elements that were not previously observable: the logic, figures of speech and style used in each text, which clarify the students' individual paths for constructing knowledge and competencies.

Thus, from the investigation of student portfolios, this article aims to analyze undergraduate students' experience during direct contact with real-life work during the "Health Promotion in Basic Education" course. This course aims to develop attitudes, knowledge and skills for health promotion effort in basic-education schools.

\section{Method}

This was an exploratory-descriptive qualitative study. Qualitative research in educational and social areas is appropriate because of the nature of the object to be studied: an object conceived in social relationships, which are interchangeable. The students are unique subjects who have a history and a critical conscience. Their actions have intention and meaning that can reveal their vision of world and their perceptions.

Therefore, the qualitative approach offers a methodological alternative that helps us understand the reality that these students' accounts express.

Qualitative research can incorporate the meaning and the intentionality inherent in the actions into relationships and social structures [14]. Such research is based on the close and indissoluble relationship between the object and the subject, which reveals not only the meanings of the study question but also the reasons, opinions, beliefs and values about that reality.

Qualitative research requires a criterion of representation to allow the generalization of the theoretical concepts to be tested. Rather than generalizing, qualitative research aims to deepen the understanding of the sample studied. Qualitative research searches for descriptive data collected during the researcher's direct contact with the studied situation, and it emphasizes the process rather than the product; that is, it is concerned with unveiling the participants' perspective [15].

The present work is a section of a larger project entitled "The Learning Process during the Nursing Teacher Degree: a study based on students' portfolios”. This study followed the recommended ethical guidelines and was approved by the EERP/USP ethics committee in research, with protocol number 0994/2009.

This study was produced in the undergraduate Bachelor and Nursing Teacher program of the Ribeirão Preto College of Nursing of the University of São Paulo. The program is a university undergraduate program offering nursing and nursing teacher degrees to work in nursing schools and in elementary schools with 6- to 17-year-olds, developing health education activities.

Brazilian law requires technical nursing courses to be run by certified nurse's with a degree, who are eligible to teach nursing and teacher training content. In addition to working in technical nursing programs, certified nurses are eligible to work in elementary schools, although there is no specific elementary discipline in nursing.

Brazilian law also requires teacher training programs to have educational and teacher training practices beginning in the early stages. The nursing teacher program in the Ribeirão Preto College of Nursing at the University of São Paulo lasts 10 semesters. Students attend courses related to nursing sciences, such as integral healthcare, anatomy, physiology, environmental health, cell biology, histology and embryology, biochemistry and history of nursing, among others. Those disciplines are integrated with teacher training disciplines, such as philosophical foundations of health and education, education and society, health promotion in basic education, didactics and education psychology.

This study is based on the health promotion in basic education course, which is part of the teacher-training coursework offered in the third semester of this undergraduate program. This course combines theoretical studies on the university campus and activities in elementary schools to create pedagogical cycles.

This course's objectives are for students to develop a critical perspective of health promotion within the basic education environment; to learn about and analyze programs and other documents with guiding principles for basic education and propositions in health; to learn about the school's political pedagogical project in terms of health promotion; to propose, plan, execute and evaluate education projects aimed at health promotion in elementary schools, with an emphasis in active methodologies.

This course brings undergraduate students into the elementary school context and offers opportunities for them to learn about teaching. It includes a 135-hour workload organized as a pedagogical cycle: immersion (in small groups, undergraduate students spend four hours with their professor in the school); provisional synthesis (discussion with colleagues and the professor about the school experience and the formulation of a learning quest); search information (readings and individual synthesis of the bibliography related to the proposed quest); new synthesis and evaluation (small-group discussion about 
the synthesis the students produced in their portfolios). The portfolios are produced throughout the courses and comprise reports of each phase. The portfolios are critical to the proposed learning process, in which students report and reflect on all stages of the pedagogical cycle. The same methodology - the pedagogical cycle - is applied in another course that focuses on nursing: Integral healthcare 2. These courses follow an integrated, competence-based syllabus that emphasizes education and real-life work. These courses adopt a critical-reflexive pedagogical approach, which is the same approach used in the political pedagogical project in the teacher training program at EERP. Other lower-workload courses support these more demanding courses.

Therefore, nursing teacher education allows the undergraduate students to work in schools with the objective of building their professional experience. Students have the chance to observe and participate in real-life contexts and develop health education activities under the supervision of their professor at the university. They use their work and experience within the elementary school, mostly emphasizing active teaching-learning methodologies. The work in elementary schools integrates the nurse's work in primary healthcare with the school staff project, creating a favorable environment for richer educational projects within the school. Although there is no specific elementary education subject in the field of nursing, Brazilian law recognizes the development of cross-disciplinary themes that lead to interdisciplinary work. To meet the demand for such work, the nursing teacher is required to prepare and develop activities in education and health that provide school children with tools to acquire scientific knowledge about health and health promotion.

The third semester class consists of 50 students divided into small groups for the courses that adopt the pedagogical cycle. Ninety per cent of nursing students are women, and the nursing profession in Brazil consists predominately of women. In the case of the course this study focuses on, there was only one man among the 20 students divided into two groups of ten. During the course, each undergraduate student produces a logbook, called a portfolio, in which they note their experience throughout the different moments of the pedagogical cycle, articulating the theory discussed throughout the course. As early as the first term of the nursing course, students are required to produce a portfolio in the Integral Healthcare 1 course, in which students participate in Basic Health Units routines. At the beginning of the Health Promotion in Basic Education course, the students receive guidance about how to produce a portfolio. At every meeting of the pedagogical cycle, or every week, the students hand in their written reports to their professors to receive feedback. The students are encouraged to exercise their ability to describe facts, analyze and reflect, producing from two to five written pages weekly.

This work aims to analyze undergraduate students' experiences during direct contact with real-life work and their understanding of aspects of the teaching-learning process. The portfolios convey students' open and hidden thoughts and offer great contributions to understanding the whole process. Therefore, this study proposes an analysis of the portfolios to examine the students' view of the teaching-learning process during its construction and/or transformation, based on their experiences with a real-life scenario.

The portfolio contains accounts of the students' individual learning processes and refers to other group members (teachers and students) and workers involved in the learning scenario, in this case, the staff of a State School of Basic Education.

Twenty students' portfolios were analyzed (the students are mentioned in this study under assumed names)during their participation in the Health Promotion in Basic Education course offered in the second year of Bachelor and Nursing Teacher Degree program of the RibeirãoPreto College of Nursing of the University of São Paulo, EERPUSP.

Each of the twenty students went through seven cycles of four-hour immersions in the elementary school throughout the semester.

All 20 portfolios were digitized and comprised a total of 1528 pages. Fourteen portfolios were handwritten; these formed the material that was analyzed in this study. These student-produced texts were classified according to themes in an attempt to identify the students' learning processes in their teacher-training course in health education in elementary schools.

Therefore, the data analysis was based on the views and references of the thematic analytical technique, a modality of content analysis [16]. This type of analysis is one of various categorization possibilities that considerthe "theme" as a unit of meaning relevant to study in question.

\section{Results}

From the analysis of the data - the portfolios produced in the "Health Promotion in the Basic Education" course it was possible to identify three main themes: approaching the school, the appropriation of knowledge about the teaching-learning process and teacher.

\subsection{Approaching the School}

When approaching the school as undergraduate students, the familiar school environment represents a new possibility. The course foresees this encounter as part of practice in the basic education school, but the student's approach is something new and almost unknown that generates anxiety and expectation; something that mobilizes their experience and history, whether personal or academic. As the student Adélia states in her account of the activity at the beginning of this course at university.

I started talking about my experience in teaching biology at a prep course for the university entry exam. So, my greatest expectation is precisely about working with a different group, possibly younger. One by one, other students talked about their many expectations. They mostly wanted to understand a bit more about basic education and mainly how nurses can work to promote health in education. So I realized that these expectations were mine as well (Adélia - introduction of discipline).

The fact that students arrive with expectations that added to their previous knowledge about the school environment seemed to prepare them for what they will find, making them active participants in the process. They will approach the new environment as subjects who search for elements of the construction they will carry out, and 
not as passive beings who expect to merely absorb information. At the same time, they find themselves open to new information while maintaining a critical eye about what they see, as observed by Cecília in her account of her first immersion in the school:

During the first visit to the school, we noticed the need for repairs for the children's safety. Some spaces of rough ground were on a slope where children were playing, whereas the sports court was closed. These areas could be better used for growing vegetables, and their products could be used in some school meals (Cecília, Immersion 1).

Cecília's statement also describes the possibilities she sees. Her statement is not an unenlightened description of the space's possibilities, but an active and proactive reflection on the mobilization of resources that might transform the environment.

During one of the activities within the immersion cycle, all of the students were startled by the sound of a fireworks explosion. This event became the theme in the provisional synthesis reports and in further phases of the cycle. The excerpt below was taken from a Provisional Synthesis report:

...as expected, we started talking about the explosion. From there, we discussed what is normal and what is not for an adolescent. We talked a lot about adolescent behavior, which is very specific and definitely something which I would like to understand better. There is a certain need in them, just like there once was in me, to break the rules. Then we talked about the belief that all of them are slum people and delinquents. I realized that I had seen them like this, making it clear that I was also a bit prejudiced. (Adélia - Provisional Synthesis, Cycle 1)

Approaching the school also seemed to allow the students to approach their own inherent concepts and prejudices, especially through writing the portfolio. That exploration was triggered by what they experienced in the practical setting.

\subsection{Appropriation of knowledge concerning the teaching-learning process}

The experience in the school raises questions that require richer background information. Students receive opportunities to enrich their background throughout the pedagogical cycle. Information about the educational processes is an important reference, as observed in the report below:

We also discussed the difference between informing and educating, passing on knowledge and raising awareness. We realized that to educate, we need methods, which fall within the three main methodologies: classical, technical and progressive (Adélia - New Synthesis, cycle 1).

We highlight the importance of discussions about the many ways of teaching and learning and the reflection that these methods are not a personal choice, unbiased, free of principles and directionality. The choice of methods may be guided a desire to maintain the status quo or may create attitudes that lead to social changes. This knowledge contributes to the wholesome development of future teacher-nurses.

After reading this book (Paulo Freire, Pedagogy of Freedom) I realized that our nursing school has a curriculum very similar to the Pedagogy of Freedom, which aims to form critical-reflexive subjects. Going through this learning process as an undergraduate student makes teaching easier when it's our turn to stimulate the subject's autonomy (Lygia, Lab of Pedagogical Professional Practice, Cycle 5).

The attempt to become acquainted with the politicalpedagogical project (PPP) came up in discussions. We noticed that this topic arose when the students entered the elementary school. This discussion encouraged learning and reflections, as Adélia's account shows:

We then saw the political pedagogical project $(P P P)$ of the school [...]. The project was established to prepare pupils for the job market. However the school performed poorly on external assessments, such as the SARESP. The objective was to promote education with equity, that is, respecting individuality [...]. The project seemed interesting, but farfetched. I believe that what is idealized doesn't always come true. (Adélia - Immersion 2)

Adélia confronts what she experienced in the school with the directives of the official document, the PPP. From this experience, during the provisional synthesis, the group came up with a question related to this theme.

Our tutor [...] joined us in this New Synthesis. She helped us better understand some aspects of the politicalpedagogical project that we had not seen. The reports were focused on the political-pedagogical project. That was the subject we tried to look deeply into because we encountered it during the immersion phase. Also, it would be part of our professional formation. The discussion about the political-pedagogical project brought up indispensable aspects. The project should be a byproduct of democratic collectivity, integrated with the community and constantly evaluated. The political-pedagogical project is an attempt to transform the current situation into something better. So, the project does not have an end. It is an ongoing process of constructing objectives during the pedagogical work (Cecília, New Synthesis, Cycle 2).

During the new synthesis, we highlight the tutor's role in supporting students in the systematization of thought in their individual search. Situations observed in field lead to reflection, to the articulation of themes discussed in other contexts/time points of the undergraduate program, allowing the critical construction of knowledge.

While giving the lesson, the teacher asked pupils to MEMORIZE it for the mid-term test [...]. Some pupils complained, saying that it was not possible to memorize it, that it was too much. The teacher gave them one month to MEMORIZE it. Open parenthesis: Is memorizing a synonym for learning? Learning takes place through a process and not through the simple act of memorizing, which gives the false impression of acquired knowledge!

According to Piaget, knowledge stems from the unevenness between the subject and the object, in which the subject acts on the object, motivated by it [...].

Recalling Freire, pupils are not bowls to be filled with knowledge without making any sense of it. From what I observed, the pupils are unaware of this fact. They should learn how to learn, learn how to think. The teacher should become an educator...Close parenthesis (Rachel, Immersion 4).

The excerpt above highlights evidence of the theoretical knowledge supporting this student's observations, showing her preference for a teaching practice that sees learning as different from the "memorized" accumulation of theory. 
Learning is a reflexive process that must make sense. It also requires learning how to think and learning how to learn. The dialogic learning and approach condition resulted in a more positive effect on critical-thinking competences [17].

\subsection{The teaching practice}

As part of the immersion proposal in the school of Basic Education, our undergraduate students must conduct educational activities that provide them with experience as educators.

Within this perspective, the activities to be developed are mostly related to science and biology-related subjects given the nursing field of knowledge, the topics established in the school curricula and needs and interests of elementary school children.

Therefore, it has become a major contribution for the nursing teacher in training to be offered the opportunity to provide teaching based on health education theories.

In such situations, new challenges regularly come up, as Cecília's account shows:

The healthy eating activity was meant to take place at the sports court. [...] After preparing the posters and the material to be used, we called the students, informing them about the theme and the groups who were to attend the workshops. While waiting for the students in the court, we became nervous, and we were getting disappointed when the students came close but turned around and didn't enter. But at the end, there were more people than we expected - about fifteen pupils. When we started the workshop, the students accepted what we were presenting. However during the workshop, they got easily distracted. We tried another approach, but in the end it was very difficult to deal with the students' attitudes without disrespecting them. At the end of this workshop, the teachers [...] told us that we could use the teachers' meeting room because they saw our difficulty. The court was an environment that allowed too much freedom. During the second workshop, we had between 10 and 13 students. It was more light-hearted, compared with the first one. We could better explain and discuss the content we had prepared. At the last workshop, I thought we would not have any students, but after calling all the groups we found three students waiting for the workshop to begin. We started talking to them, introducing ourselves, and then three more students arrived. At this workshop, the pupils seemed to be more involved in the theme, and we got on well with them, getting more satisfactory feedback. [...] Even going through some difficulties, I think we achieved most of our proposed objectives for the activity (Cecília, immersion 7).

Thus, Cecília's experience provided her with an understanding of that activity beyond the task itself, helping her address unforeseen challenges and initial disappointment.

The role of the educator, even a developing one, allows new situations to trigger new insights. Zélia's report shows some of her own process:

During the lesson, we saw the need to explain the difference between induced abortion and spontaneous abortion. The girls seemed shocked by the possibility of a physiological abortion; one of them said: "if my body wanted to expel my baby, I'd kill my body". I see that making this difference clear was necessary so that there was no false impression that every interrupted pregnancy would be intentional. This topic had not been planned for that lesson (Zélia, immersion 7).

In this case, the challenging situation led Zélia to reflect about the activity that was proposed and her own planning, making her think about the flexibility and possibility of change in the lesson plan in response to concrete experience during the educational activity.

\section{Discussion}

According to [18], “The student's personal experience becomes the main basis of the pedagogical work. (...) the passiveness of students, as well as underestimating their personal experience are, from the scientific point of view, the most serious mistake, along with the false rule that the teacher is everything, and the student is nothing. On the contrary, psychological criteria require recognizing that in the education process, the student's personal experience is everything. (...) the student's personal activity must be the basis of the educational process, and all the art of the educator must be restricted to guide and regulate this activity."

Likewise, the dialogical approach of competence and meaningful learning recognizes and takes into consideration students' previous experience. Students are allowed to relate their experience to new knowledge as they construct, deconstruct and rebuild knowledge and values. Such knowledge and values will guide the expected attributes of a given field according to socially determined standards of excellence [19].

This reflection and attitude comes from a criticalreflexive perspective of the teaching and learning process. In real or simulated professional situations, this process enables deeper learning about real-life work, which complements the construction of knowledge.

In the dynamic articulation between working and teaching, practice and theory, and teaching and community, students and tutors build potentially meaningful knowledge that improves the quality of professional development [20].

Regarding narratives, one study [21] highlights that "At the same time, the subjects individually organize their ideas for the report, which can be written or oral. They rebuild their experience in a reflexive form and, therefore, end up producing a self-analysis that creates a new basis for comprehending their own practice” (p.2).

This is observed in Adelia's portfolio: her experience in the school is enriched by discussions with colleagues and tutor and the need to organize her ideas for the written report. She comes to a thoughtful conclusion about the experience as a whole. Furthermore, writing improved her self-awareness, resulting in her comment: "I was also a bit prejudiced."

The portfolio is an instrument that improves reflection about practice, allowing the construction of knowledge and the personal and professional development of both students and tutors [22]. Tutors indicate that the portfolio is a powerful means of supporting students' development because the objective of portfolio elaboration does not focus only on what is written. Above all, the students must reflect upon themselves when reading and working 
through reflexive and dialogical narratives, thus expanding their search for answers.

The portfolio clarifies the self-reflection processes for both the student and the tutor [23]. Portfolios allow students to express themselves, contextualize learning within their life histories, attribute meanings to their experience and interpret it in their own way. Portfolio creation is a developmental strategy in which students build meanings from their own previous experience.

From the statements above, it is possible to reinforce that in the narratives presented for reflection, self-criticism and the search for meanings guided and showed the potential of portfolio elaboration as a critical-reflexive instrument. Self-reflection gives way to new meanings, allowing students to build and rebuild both their knowledge and their values. Portfolios also contribute to autonomy in students' development, allowing freedom to develop reflection skills. Portfolios encourage students to expand their theoretical-conceptual background and to reformulate their views on learning and continuous evaluation [24].

During this process, students' own experience in the undergraduate program allows significant learning via different courses. This learning occurs because students revisit their academic experience and history. Reference [19] shows "meaningful learning requires a pro-active attitude which fosters relationships between the new and the elements already present in the cognitive framework. This framework represents a set of knowledge schemes formed of data, concepts, situations, facts, sequence of events, actions and sequence of actions, which can be more or less organized and coherent and which allow the creation of a wide range of networks, varying in extension and complexity” (p. 374).

From what we have observed, and as Vygotsky [25] and Paulo Freire [26] put it, human beings become subjects by means of reflecting on their situation and their environment. Therefore, each and every educational process should lead the learner into awareness and critical attitude, towards provoking changes in their reality.

This raising of awareness comes from the perspective of evolving from naïve awareness to critical awareness. That is, to that type of awareness which has overcome two limits of inertia: ignorance and human powerlessness in the face of reality [27].

For [27], one of the tutor's primary tasks is "to help learners acquire methodological strictness, with which they must 'approach' the cognitive objects” (p. 14). The tutor listens carefully to students' accounts and views, supporting them in the confrontation between the empirical experience brought by the group and the theories about it. Cecília's account shows an apprehension of important concepts about the political pedagogical project.

Health education is a field of practical knowledge in nursing focused on the creation of personal ties, expertise development, and complementary dimensions among health care, planning and everyday procedures [28]. Along these lines, the concept of health education consists of an integrated path that includes several factors: care, a space for reflection about actions taken, support from various fields of knowledge, cultural meaning in democratic group decisions, and the ability to lead to individual and collective changes [29].
The role of the nurse must take an interdisciplinary and intersectorial perspective, as a reference for health promotion. For this reason, nurse should: develop some work through educational activities, stimulating social participation and reflection; contribute to training of health education professionals in the school; engage students, families and whoever is needed to carry out health education projects; recognize the key role of children and adolescents as subjects with rights to health and education and who can construct citizenship.

Beyond these aspects, such perspective is based on epistemological bases of social-interactionist thinking; that is, placing learners and teachers as participants in the same mediation process. Such mediation is a precondition of the relationship between the individual and the social other, in which subjects are active in their learning process and development. People are not subject to biological or social determinism [30].

We understand human development as a process of setting oneself free via cultural and historical ownership through a dialectical relationship with one's own social and cultural environment.

For [25], all learning is based on concrete social relationships, hence the importance of immersion in the practice for the teacher formation. It is the activity, in the context of historical-cultural approach, that mediates the individual and the objective reality. According to [31], such assumptions “[...] help better understand the teacher's work and his/her professional formation. The focus is on the nature and the structure of human activity, the relationship between teaching and learning and human development. These factors make it possible to understand professional development through real-life work and everyday procedures in the context of work and not only through theory, as seen by technical rationality and common sense conception about formation, which still strongly rules in the schools and in teacher-training institutions” (p. 7).

The authors value and highlight the importance of the student's actions to his/her learning. Nevertheless, the teacher's role is fundamental to this process.

When we give so much importance to the student's personal experience, are we neutralizing the teacher's role? Can we substitute the previous formula "The teacher is all, the student is nothing” with its reverse: "The student is all, the teacher is nothing?" Absolutely not. If, based on scientific evidence, we deny the teacher's ability to exert a direct educational influence or teacher's mystic power to "model souls", it is precisely because we recognize that the importance of the teacher is immeasurably great [18].

This work focuses university tutors' role in coaching undergraduate students in their training. Examples of that role are found in the students' quotes: "The tutor [...] joined us in this New Synthesis; her presence helped us to better understand some aspects of the politicalpedagogical project we had not seen," and "the teachers [...] told us that we could use the teachers' meeting room, because they saw our difficulty." Reference [18] indicates teacher as the one who creates the condition that allows learning to take place. For the experience to make sense, reflection about it is fundamental, and the teacher has an important role in this sense. "The aim of education is not the adaptation to the existing environment, which happens 
naturally, but the creation of human beings who see beyond their own environment".

It is important that the tutors who coach those undergraduate students develop a teaching process for themselves when helping students become teachers. The tutors' experience throughout the process is fundamental. Tutors learn to teach through experience and discussions in this field and from models and relationships created with their own tutors.

\section{Conclusions}

This study includes the nursing education in actions that empower subjects' self-expression in their social and cultural lives, thus encouraging autonomy. The study is based on a dialogical model of health education that offers theoretical and practical tools for actions in health and nursing in elementary school environments. Additionally, the study relates to science subjects in an expanded dimension of the social conditions of the health-illnesscare, thus consolidating a model of integral healthcare.

In compliance with the theoretical perspectives discussed in this paper and those gained from reflections and participation of nursing students during education practice in schools, it is important to mention that we consider education as an emancipatory pedagogical thinking-and-doing process. That is, we believe in the possibility of developing intellectual and social autonomy as an individual and as a group. Therefore, we consider both the undergraduate university student and the elementary school student active agents in creating meanings in the teaching-learning process.

The basis for pedagogical work is the learner's personal experience. When shared, this personal experience creates processes of significance that allow the emergence of knowledge, practice, and ways of taking action. The use of pedagogical proposals based on dialogical competence and meaningful learning is presented as a fundamental factor for achieving the new professional nurse's description: generalist, humanist, reflexive and critical. The analysis of the accounts presented here indicates the possibilities for beginning this developmental process, such as the use of the pedagogical cycle and the reflexive portfolio. The pedagogical cycle allows a greater transfer of training to real-life work, whereas the portfolio refines the reflection about the challenges of professional practice. This reflection emerged from the three themes presented here: approaching the school, appropriation of knowledge about the teaching-learning process and teaching practice.

The accounts in the portfolios show students' reactions to realities that were initially unfamiliar to them and indicate the importance of such experience during the undergraduate program. The portfolios allow students to transcend mere observation or description to indicate the possibilities of transforming what they experienced, the work with one's own prejudice, and provide evidence of the reflection the students achieved. Moreover, the difference between one's previous experience and the experience of professional practice promotes new knowledge about the teaching-learning process. The reflections presented in the portfolios points to the dynamism of this process, illustrating the way some students used theory to formalize new knowledge. Lastly, the students highlighted the new teaching skills they acquired. During this practice experience, "unexpected incidents" arose from the idealized situation designed in the lesson plan. However, those unexpected incidents are part of teachers' routines; they challenge their knowledge and ability, leading them to search for solutions with colleagues and tutors and thus build competency.

With the experience reported here, we hope to contribute to the formation of a better-prepared professional who is critical and responsible in the proposition and development of health promotion programs in basic education schools.

\section{Acknowledgements}

This material is based on work supported by the FAPESP/2009. It is also supported by CAPES, Coordination for the Improvement of Higher Level Personnel - Proactive Health Education Project: 2037/2010. Any opinions, findings, conclusions or recommendations expressed in this material are those of the author(s) and do not necessarily reflect the views of the FAPESP and CAPES.

\section{References}

[1] Constituição da República Federativa do Brasil de 1988. (1988). Brasília: Senado Federal.

[2] Ceccim, R.B., Armani, T.B. and Rocha, C. (2002). O quedizem a legislação e o controle social emsaúdesobre a formação de recursoshumanos e o papel dos gestorespúblicos, no Brasil. Ciência \& Saúde Coletiva, v. 7, 2, p. 373-383.

[3] Lei n. 9.394, de 20 de dezembro de 1996. (1996). Estabelece as Diretrizes e Bases de Educação Nacional. Diário Oficial da União, Brasília. Seção 1, p. 1-27.

[4] ConferênciaNacional de Saúde, 12. (2004). Relatório final. Brasília: Ministério da Saúde.

[5] Parecer CNE/CES 3, de 7 de novembro de 2001. (2001). Ministério da Educação. Conselho Nacional de Educação.: Diretrizescurricularesnacionais do curso de graduaçãoemenfermagem. Brasília.

[6] Gazzinelli, M.F. et al. (2005). Educaçãoemsaúde: conhecimentos, representaçõessociais e experiências da doença. Cad. Saúde Pública, v. 21, n. 1, p. 200-206.

[7] Geertz C. (1978). Ainterpretação das culturas. Rio de Janeiro (RJ): Zahar.

[8] Lam, D. (2004). Problem-based learning: an integration of theory and field. Journal of Social Work Education. v. 40, n. 3, p. 371-38.

[9] Corrêa, A. K., Santos, R.A., Souza, M.C.B.M. and Clapis, M.J. (2011). Problem-solving methodology and its implications for the faculty work: experience report. Educaçãoem Revista, Belo Horizonte, v. 27. n. 03. p. 61-78. dez.

[10] Silva, R.F.; Sá-Chaves, I. (2008). Formaçãoreflexiva: representações dos professoresacerca do uso de portfólioreflexivonaformação de médicos e enfermeiros. InterfaceComunic, Saúde, Educ; v. 12, n. 27, p. 721-34.

[11] Zanotto, M. A. C.; De Rose, T.M.S. (2003). Problematizing one’s own reality: analysis of an experience of continuing education. Educação e Pesquisa, São Paulo, v. 29, n. 1, p. 45-54, jan./ jun.

[12] Berbel, N. N. (1998). "Problematization" and Problem-Based Learning: different words or different ways? InterfaceComunicação, Saúde, Educação, v. 2, n. 2,.

[13] Mishima SM, Fortuna CM, Scochi CGS, Pereira MJB, Lima RAG and Matumoto S. (2009). Maria Cecília Puntel de Almeida: a trajetória de umaprotagonista da enfermagembrasileira. Textocontexto - enferm. 18 (4): 773-80.

[14] Minayo, M.C.S. (2010). O desafio do conhecimento: pesquisaqualitativaemsaúde. 12. ed. São Paulo: HUCITEC.

[15] Ludke, M. and André, M. (1986). Pesquisaemeducação: abordagensqualitativas. São Paulo: EPU. 
[16] Bardin, L. (2004). Análise de Conteúdo. 3. ed. Lisboa: Edições 70

[17] Frijters, S., Dam, G. T., and Rijlaarsdam, G. (2008). Effects of dialogic learning on value-loaded critical thinking. Learning and Instruction, v. 18, n. 01, p. 66-82.

[18] Vygotsky, L. S. (1992). Educational Psychology. St. Lucie Press, Florida.

[19] Lima, V.V. (2005). Competência: distintasabordagens e implicaçõesnaformação de profissionais de saúde. Interface Comunic, Saúde, Educ, v. 9, n. 17, p. 369-79.

[20] Araújo, D. (2007). Noção de competência e organização curricular. Revista Baiana de Saúde Pública. 31 (Supl. 1): 32-43.

[21] Cunha, M. I. (1997). Conta-me agora! As narrativascomoalternativaspedagógicasnapesquisa e no ensino. Rev. Fac. Educ. vol. 23 n. 1-2 São Paulo.

[22] Ferreira, M C.I., and Bueno, A.L.G. (2005). O portfóliocomoavaliaçãonaeducação superior: Uma experiência de sucessoem um curso de pedagogia, em: Santos, C.R. (Org.): Avaliaçãoeducacional. São Paulo: Editora AVERCAMP.

[23] Sá-Chaves, I. (2000): Portfóliosreflexivos: estratégia de formação e de supervisão. Aveiro: Universidade.
[24] Silva, C.M.S.L.M.D, and Tanji, S. (2008). O portfólioreflexivo: pareceres dos estudantes de enfermagem. Revistalberoamericana de Educación. n. 46/6.

[25] Vygotsky, L. S. (1978). Mind in Society. Cambridge, MA: Harvard University Press.

[26] Freire, P. (2011). Pedagogia do oprimido. 50ª ed. São Paulo: Paz e Terra.

[27] Freire, P. (2007). Pedagogia da Autonomia: Saberes Necessários à Prática Educativa. 35 ed. São Paulo: Paz e Terra.

[28] Vasconcelos E.M. (2006). Educação popular e aatenção à saúde da família. 3 ed. São Paulo: Hucitec. (Saúdeem debate: 130).

[29] Machado MFAS, et al. Integralidade, formação de saúde, educaçãoemsaúde e as propostas do SUS - umarevisãoconceitual. Ciênc. saúdecoletiva, Rio de Janeiro, v. 12, n. 2, p. 335-42, 2007.

[30] Vygotsky L. S. (1986) Thought and Language. Cambridge, MA: MIT Press.

[31] Libâneo, J.C., and Freitas, R.A.M.M. (2006). Vygotsky, Leontiev, Davydov Trêsaportesteóricospara a teoriahistórico-cultural e suascontribuiçõespara a didática. In: IV Congresso Brasileiro de História da Educação - SBHE, 2006. Anais...Goiânia, GO: Editora Vieira/UCG. 